\title{
OXIDATIVE STRESS - AN UPDATE AND INSIGHT IN THE ROMANIAN FAMILY PHYSICIAN'S ADOPTION OF THE CONCEPT
}

Florian Berghea, Camelia Elena Berghea, Mihai Abobului

Carol Davila University of Medicine and Pharmacy, Bucharest, Romania

Corresponding author: Camelia Elena Berghea

E-mail: camelia.berghea@umfcd.ro

\begin{abstract}
Our investigation sought to understand what the family physicians think about the oxidative stress (OS) and its role in various medical pathologies. Using a structured interview the concept was evaluated on six domains: general interest in OS, general knowledge about OS, acceptability of OS concept as a valid explanation of the daily seen pathologies, the perceived role of OS in rheumatic diseases (and also in non-rheumatic), therapeutic options covering this concept. We found a suboptimal knowledge and utilization of OS in practice but an increasing interest in.
\end{abstract}

Keywords: oxidative stress, inflammation, arthritis, antioxidants.

\section{Rezumat}

Studiul nostru și-a propus să ofere o înțelegere mai bună despre ce cred medicii de familie despre stresul oxidativ (OS) și rolul său în diversele patologii medicale. Folosind un interviu structurat, acest concept a fost evaluat pe șase domenii: interesul general cu privire la OS, cunoștiințele generale despre OS, acceptarea acestui concept ca o explicație validă a patologiilor evaluate zilnic, rolul perceput al OS în cazul bolilor reumatice (respectiv, nonreumatice), opțiunile terapeutice asociate acestui concept. Am identificat o cunoaștere și utilizare suboptimală a conceptului de OS, dar un interes în creștere.

Cuvinte cheie: stres oxidativ, inflamație, artrită, antioxidanți.

a. Endogenous

- mitochondria

- xanthine oxidase

- peroxisomes

- inflammation processes

- phagocytosis

- arachidonate pathways

- ischemia b. Extemal

- smoking

- environmental pollutants

- radiation

- drugs

- pesticides

- industrial solvents

- ozone 


\section{INTERNAL}

\section{Original Papers}

\section{Introduction}

The concept of oxidative stress (OS) becomes more attractive in the last period for several reasons. First is our limited capacity to explain most of the degenerative pathologies in the key to inflammation (chronic or acute). Then is the increasing interest of the general public for so called "healthy life and healthy food" - for sure the "antioxidant" feature is considered healthier than, let's say, Ecompounds supplementation (although there is a quite vague knowledge of what Ecompounds are, in the same general population (1). Last but perhaps most important, the concept of oxidative stress gained a special interest during COVID-19 pandemic, when a number of theories put it in the eye of the cytokine storm and subsequent fatal evolutions.

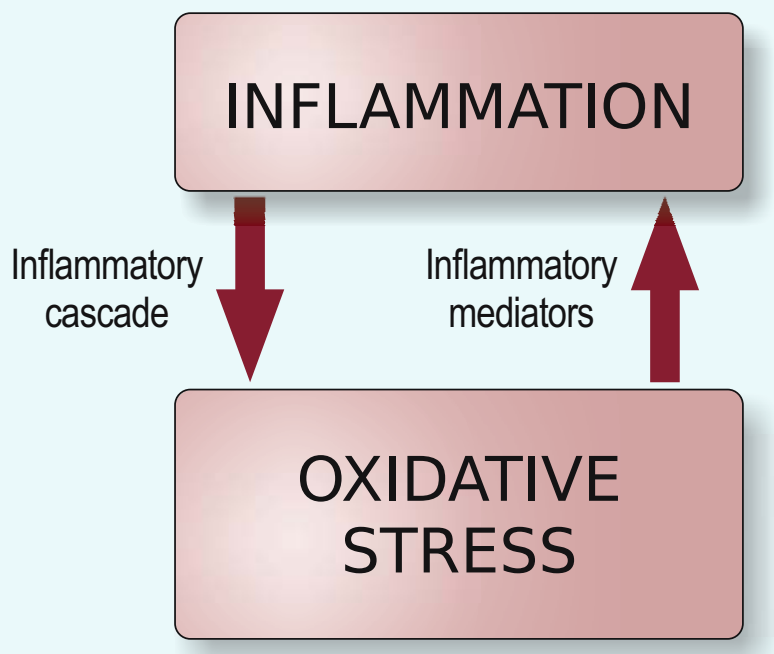

We understand oxidative stress (OS) as an imbalance between the production and elimination of oxygen containing free radicals (these are defined as reactive oxygen species). The reactive oxygen species (ROS) are produced from endogenous sources (as in mitochondrial oxidative phosphorylation) or from interaction with exogenous reagents (see table 1).

A normal production of ROS contributes to normal metabolism, while a disbalanced (increased) production is the pathway to cellular damage. ROS are small molecule metabolites of oxygen with a high reactivity that lead to generation of REDOX reactions ${ }^{(4)}$. Structural the most studied ROS are: superoxide anion $\left(\mathrm{O}_{2}{ }^{-}\right)$, hydrogen peroxide $\left(\mathrm{H}_{2} \mathrm{O}_{2}\right)$, hydroxyl radical $(\mathrm{OH})$, hypochlorous acid $(\mathrm{HOCl})$, peroxy-nitrite anion (ONOO-), and nitric oxide (NO) ${ }^{(4)}$. Apart from ROS (that derive from oxygen) there are free radicals that derive from Nitrogen or Sulfur element these are known as Reactive Nitrogen Species (RNS) and Reactive Sulfur Species $(\text { RSS })^{(2)}$. There are two opposite chemical reactions included in the Redox system: oxidation and reduction. During the oxidation process there is an oxygen gain and lose hydrogen or electrons; during the reduction process oxygen is lost and hydrogen or electrons are gained.

It is thought that free radicals interfere with various compounds of normal cell like 
proteins, lipids, sugars or more complex structures as DNA and RNA $A^{(3,5,6)}$.

These targets are deeply affected and subsequently their normal function is totally or in greatest extent lost. A particularly good insight has been made regarding DNA and RNA molecules - OS is known to produce base deletion, chromosome rearrangements, base modification, or DNA-protein cross links.

The pool of delirious changes made by OS is higher with age that could explain, in the view of many authors, why the elderlies have a progressive increased risk of developing several conditions like atherosclerosis, various inflammations and cancers, or even the process of aging. Among the diseases that have studied in correlation with OS there are solid arguments for all inflammatory diseases (arthritis, vasculitis, systemic erythematous lupus), ischemic diseases, gastric ulcers, hypertension, neurological disorder (Alzheimer's disease, Parkinson's disease, muscular dystrophy $)^{(7)}$.

Among the mechanisms that are of particular interest linking OS and chronic inflammation response are the recruiting process of immune cells to the damaged $\operatorname{areas}^{(8)}$ and activation of inflammation associated transcription factors such as nuclear factorkappa B (NF-kB) and activator protein-1 (AP-1) with subsequent production of inflammatory mediators $^{(9)}$. It is known that NF-KB promotes expression of proinflammatory cytokines (IL1, IL-6, IL-8) and TNF- $\alpha$, cyclooxygeneases- 2 and lipoxygena-se ${ }^{(10)}$. A very concise representation of the link between OS and inflammation is presented in figure $1^{(10)}$.

Therapeutic solutions in the management of excessive OS (named with the general term of "antioxidants") are mainly based on supplementary nutrients but some more specific molecules have been also introduced in clinical practice. The antioxidants are defined as "any substance that delays, prevents or removes oxidative damage to a target molecule"(11). Although the human organism possess a very capable endogenous antioxidant system this is not capable to keep the free radicals at a sufficient low level and is dependent of exogenous (mostly dietary) antioxidants ${ }^{(12)}$.

\section{Objective}

Our study aimed to investigate how the updated concept of oxidative stress has been adopted by Romanian family practitioners.

\section{Materials and Methods}

Using a structured interview the concept of oxidative stress was evaluated on six domains: general interest in OS, general knowledge about OS, acceptability of OS concept as a valid explanation of the daily seen pathologies, the perceived role of OS in rheumatic diseases (and also in nonrheumatic), therapeutic options covering this concept.

Family physicians have been contacted by phone during August-September 2020 following a referral method - each doctor indicated a colleague as a potential participant. The answers have been recorded in a free form. No GDPR sensible information (as name, specific location of practice or gender) have been recorded. The protocol was ethically approved by ethical committee of the Center for Studies on Medical Technologies (Centrul de studii asupra tehnologiilor medicale).

\section{Results and Discussion}

- General interest in OS was appreciated as moderate to high. Some responders 


\section{INTERNAL}

\section{Original Papers}

indicated that have been exposed to education materials about OS but this was especially done during postgraduation period and for not such a long period of time. Others explained their medium interest through the novelty of the concept that would require, in their view, a persistence in time: "it is not from our planet" - a doctor said. However, none considered it as not scientifically supported.

- The general knowledge about OS was appreciated as poor to insufficient. The term of OS was familiar for about half of the responders and few more were familiar with "free radicals" term, too. But no one has been ready to name a free radical or a pathological pathway. However, all doctors mentioned that they do have some patients that are asking about antioxidants in their diet.

"Some of my highest educated patients do ask me sometime about antioxidants they hear from media" - said a doctor. Additionally, all doctors declared that antioxidants drugs and supplements are available on the market, but a small proportion mentioned a trade name.

- The acceptability of OS concept as a valid explanation of the daily seen pathologies was noted as low. Almost all doctors declared that scientifical explanation comes and go to often to not be cautious to any new concept. In addition, the concept should be tested with therapeutic solutions to prove the validity and such instruments are still not enough used by the responders.

- The perceived role of OS in meumatic diseases was noted low but superior to the role in non-rheumatic diseases. Compared with the perceived role of inflammation (noted very high) most of responders considered OS as possible involved in rheumatic diseases but with unknown extent. However, no responder was satisfied by the general level of knowledge in rheumatic diseases pathology.

- The perceived role of os in nonrheumatic diseases was noted low except for cardiac pathology (noted medium to high). At the same time both OS and inflammation have considered to be more or less equally involved in cardiovascular pathology.

- As for therapeutic options covering OS just a small proportion of responders indicated therapeutic options other than vitamins and metals (Vitamin C, E and Selenium have been recognized but not spontaneously named as antioxidants). Few responders mentioned a trade name and few mentioned Q Co-enzyme. However, all responders declared that antioxidants are present in the Romanian market. 


\section{Conclusions}

Oxidative stress is a concept that attract an increasing level of interest to explain various pathologies. Among all these, rheumatic and cardiovascular diseases as neoplasia, too have the most robust support. However, the concept is not enough known by the pool of family practitioners and more high value information need to be directed towards. The knowledge about therapeutic instruments in this area is fragmented and more direct experiences are needed to generate a proper utilization of the concept.

\section{References}

1. Evans G, de Challemaison B, Cox DN. Consumers' ratings of the natural and unnatural qualities of foods. Appetite. 2010 Jun 1;54(3):55763.

2. Carocho M, Ferreira ICFR. A review on antioxidants, prooxidants and related controversy: Natural and synthetic compounds, screening and analysis methodologies and future perspectives. Food and Chemical Toxicology. 2013 Jan 1;51:1525.

3. Lobo V, Patil A, Phatak A, Chandra N. Free radicals, antioxidants and functional foods: Impact on human health. Pharmacogn Rev. 2010;4(8):11826.

4. Reactive Oxygen Species (ROS) | AAT Bioquest [Internet]. [cited 2020 Sep 21]. Available from: https://www. aatbio.com/catalog/reactive-oxygenspecies-ros-indicators-probes-quantification-kits
5. Valko M, Rhodes CJ, Moncol J, Izakovic M, Mazur M. Free radicals, metals and antioxidants in oxidative stress-induced cancer. Chemico-Biological Interactions. 2006 Mar 10;160(1):140.

6. Dizdaroglu $M$, Jaruga $P$, Birincioglu $M$, Rodriguez $H$. Free radical-induced damage to DNA: mechanisms and measurement1, 2 1This article is part of a series of reviews on "Oxidative DNA Damage and Repair." The full list of papers may be found on the homepage of the journal. 2Guest Editor: Miral Dizdaroglu. Free Radical Biology and Medicine. 2002 Jun 1;32(11):110215.

7. Stefanis L, Burke RE, Greene LA. Apoptosis in neurodegenerative disorders. Current Opinion in Neurology. 1997 Aug;10(4):299305.

8. Pashkow FJ. Oxidative Stress and Inflammation in Heart Disease: Do Antioxidants Have a Role in Treatment and/or Prevention? [Internet]. Vol. 2011, International Journal of Inflammation. Hindawi; 2011 [cited 2020 Sep 22]. p. e514623. Available from: https://www.hindawi. com/journals/iji/2011/514623/

9. Hussain SP, Harris CC. Inflammation and cancer: An ancient link with novel potentials. International Journal of Cancer. 2007;121(11):237380.

10. Lee Y-M, Song BC, Yeum $K-J$. Impact of Volatile Anesthetics on Oxidative Stress and Inflammation [Internet]. Vol. 2015, BioMed Research International. Hindawi; 2015 [cited 2020 Sep 22]. p. e242709. Available from: https://www.hindawi.com/journals/bmri/ 2015/242709/

11. Halliwell B. Biochemistry of oxidative stress. Biochem Soc Trans. 2007 Nov 1;35(5):114750.

12. Flavonoids as Antioxidants | Journal of Natural Products [Internet]. [cited 2020 Sep 22]. Available from: https://pubs.acs.org/doi/abs/10.1021/np9904509 